\title{
Five Common Myths About Floating Exchange Rates
}

\author{
DALLAS S. BATTEN and MACK OTT
}

$\mathrm{M}$ of the Bretton Woods system of fixed exchange rates. 1 Because of its demonstrated inability to provide for the institutional adjustment of exchange rates necessary to incorporate change, there is general agreement that the Bretton Woods system, under which world trade was organized from 1945 to 1971 , could not have been maintained. ${ }^{2}$ Moreover, the viability of the system of floating exchange rates is buttressed by both a massive

Dallas $S$, Batten and Mack Ott are senior economists at the Federal Reserve Bank of $S t$. Louis. Sarah R. Driver provided research assistance.

'Since 1973-74 every country has faced the choice of whether to allow its currency to float; most countries have chosen not to float freely:

Of the 146 countries comprising the membership of the International Monetary Fiand $37 \mathrm{peg}$ their currency to the U.S. Dollar, 13 to the exchange rate of the French Frane, 14 to SDBs, 24 to some other composite unit, and 5 to some other carrency. Eight countries, the nembers of the European Monetary System, peg their currencies to the Furopean Currency Unit and to each other while thoting freely against other cumencies. Thirty-seven countries have miscellaneous arrangements. Only eight countries, (motuling the United States) permit their individual currencies to float foely.

International Letter, Federal Reserve Bank of Chicago (May 20, 1983) p. 1. This result neither refutes the advantages of floating rates nor surprises foating-rate advocates. Both Milton Friedman, in Milton Friedman and Robert V. Roosa, The Balance of Payments: Free Versus Fixed Exchange Rates (American Enterprise Institute for Public Policy Research, 1967), p. 121, and Harry G. Johnson, "The Case for Flexible Exchange Rates, 1969," this Review (June 1969), pp. 12-24, have noted that a fixed rate has advantages for small open economies and that closely knit trading partners would find a joint float preferable. Moreover, they argued that only the most important currencies (the dollar, the mark and the yen) have to be market determined for the advantages of floating rates to accrue.

${ }^{2}$ For examples, see Leif $H$. Olsen. "The Nostalgia for Bretton Woods," Wall Street Journal, May 25, 1.983; Irwin L. Kellner, The Manufacturers Fanover Economic Report (May 1983); and David R. Francis, "Why Wonld Bankers Look Askance at Returning to Fixed Exchange Rates," Christian Science Monitor, May 24, 1983. body of theoretical support and a continuing emergence of institutions that facilitate international trade under such a system. ${ }^{3}$

Despite the theoretical arguments and historical evidence supporting the benefits of floating exchange rates, there have been many calls for a return to fixed exchange rates. ${ }^{4}$ The criticisms of floating exchange rates have emanated from a variety of spokesmen businessmen, politicians and columnists - and have led to media discussions that blame floating exchange rates for a wide variety of economic ills, both domestic and international. When carefully considered, however, most criticisms of floating exchange rates share some common misinterpretations of international data or misunderstandings of exchange rate determination.

Rather than confronting the broad issue of whether Hoating or fixed exchange rates are preferable, we choose to examine five common myths about floating exchange rates that have received considerable support in the financial and general press. Since these

${ }^{3}$ For examples, see Milton Friedman, "The Case for Flexible Exchange Rates," in his Essays in Positice Economics (University of Chicago Press, 1953), pp. 157-203; Johnson, "The Case for Flexible Exchange Rates, 1969"; Johan Myhrman, "Experiences of Flexible Exchange Rates in Earlier Periods: Theories, Evidence, and a New View, Scandinavian Journal of Economics V. 78, No.2 (1976), pp. 169-96; and Roy A. Batchelor and Geoffrey E. Wood, "Floating Exchange Rates: The Lessons of Experience," in Batchelor and Wood, eds., Exchange Rate Policy (St. Martin's Press, 1982), pp. 12-34.

the best known among these is President Francois Mitterrand of France who, addressing a recent meeting of the Organization of Economic Cooperation and Development in New York City, said: "The time has come to think of a new Bretton Woods. . Outside this proposition, there will be no salvation." "Mitterrand Seeks Parley to Revamp Monetary System," New York Times, May 10, 1983. 
misconceptions frequently are based on a faulty understanding of exchange rate determination, we first outline the elements of the modern asset market view of exchange rates.

\section{ELMENTS OF EXCHANGE RATH DTTWTMNATON}

An exchange rate is simply the relative price of two assets - one country's currency in terms of another's - which is determined in relatively efficient markets in the same manner as are the prices of other assets, such as stocks, bonds or real estate. Unlike the prices of services or nondurable goods, asset prices are influenced comparatively little by current events. Thus, for example, daily fluctuations in the flow of buyers to a farmers' market have a great impact on the prices of vegetables sold there but almost no impact on the price of the farms producing those vegetables; instead, longer-term expectations of demands and supplies of vegetables govern the farms' values. Similarly, the values of national currencies do not rise or fall with contemporaneous exports or imports of goods and services but rather with the long-term expectations of their countries' economic prospects.

Given the dominance of this long-term perspective in exchange rate determination, several characteristics of the modern theory of asset price determination are of both theoretical and empirical relevance. First, asset price movements are irregular and unpredictable; that is, they behave as a random walk in the short run. Since the current price already reflects the expected future value of assets, this observed unpredictability can reflect only unexpected events or "news."

\footnotetext{
${ }^{5}$ The asset market view of exchange rate determination sketched in this section follows that of Michael Mussa, "Empirical Regularities in the Behavior of Exchange Rates and Theories of Foreign Exchange Markets," in Karl Brunner and Allan H. Meltzer, eds., Policies for Employment, Prices, and Exchange Rates, CarnegieRochester Conference Series on Public Policy (supplement to the Journal of Monetary Economics, Volume 11, 1979), pp. 9-57. It is the predominant view of most international economists due to its ability to explain many of the empirical regularities in the behavior of exchange rates that have been whibited throughout our experience with floating exchange rates. See also Jacob Frenkel, "Flexible Exchange Rates, Prices, and the Role of 'News': Lessons from the 1970s," Journal of Political Economy (August 1981), pp. 665705. It should be noted, at the outset, that we do not intend to present a complete theory of exchange rate determination, nor even extend the state of the current theory. Instead, we will follow up this sketch of accepted theory with what we consider to be widely held misconceptions concerning both the determination of exchange rates and the consequences of exchange rate changes, and then demonstrate how these misconceptions are inconsistent with both the data and generally accepted economic theory.

${ }^{6}$ See Frenkel, "Flexible Exchange Rates, Prices, and the Role of "News"."
}

Second, exchange rates reflect anticipated relative inflation rates that are generated by both past and expected future monetary and fiscal policies of the countries whose currencies are valued in the exchange rate. Therefore, currencies of countries with relatively lower expected inflation rates are cheaper to hold over time and are in greater demand at the same price than those with higher expected inflation rates. Consequently, higher-inflation currencies will tend to depreciate relative to lower-inflation currencies.

Third, in the long run, exchange rates move to maintain purchasing power parity (PPP) among the various countries; PPP means that a dollar's worth of the foreign currency (at the current exchange rate) will buy the same amount of goods in the foreign country as a dollar will buy in the United States. If so, the ratio of the U.S. price level to that of the foreign country will equal the exchange rate. Nonetheless, due to interest rate movements, among other things, short-run departures from this condition are observed frequently. Also, over long periods, relative scarcities and labor productivities in different countries may change at different rates, altering the equilibrium absolute PPP. Therefore, a somewhat weaker form of this condition, relative purchasing power parity (RPPP), which asserts that changes in the exchange rate will equal changes in the ratio of U.S. to foreign price levels, is a more reliable, but not infallible, short-run guide.

Fourth, paralleling PPP is a condition called interest rate parity (IRP). IRP means that the real yield - net of expected inflation and expected exchange rate changes - obtained by investing in securities in any given currency will be roughly equal to the yield obtained from securities in any other currency. For example, IRP implies that a German investor would expect to obtain the same return from buying a shortterm Bundesbank security and then selling it three months later as he could alternatively obtain from selling deutsche marks (DMs) to get dollars, using the dollars to buy a U.S. Treasury bill, selling it three months later and then using the dollar proceeds to buy DMs. Other things equal, if the real yield in Germany rises relative to that in the United States, the dollar would depreciate.

Each of these four elements of exchange rate determination operates simultaneously so that exchange rate movements can seldom, if ever, be attributed to a single cause. Conversely, all of these elements can be understood to result from the aggressive interactions of well-informed, profit-seeking traders transacting in well-organized, international currency markets. Any trader who by his possession of some new information 
sees an opportunity for profit will make transactions which will tend to move exchange rates both to reflect that new information and to foreclose the opportunity for further profit. This tendency for market prices of assets, such as exchange rates, to reflect quickly all relevant new information is the primary characteristic of an "efficient market." This efficient market property will be useful in examining the five common myths about floating exchange rates.

\section{NUTII RTES 夏TNDER INTERTATIONAL TRADE.}

Proponents of a return to fixed exchange rates argue that since exchange rate fluctuations are obviously larger in a floating rate system, there is more uncertainty associated with international trade in such a system. Consequently, they contend that floating exchange rates raise more impediments to international trade than would exist if exchange rates were fixed. ${ }^{7}$

A floating exchange rate is one whose equilibrium value is determined by market forces, not by the intervention of monetary authorities in foreign exchange markets. ${ }^{8}$ As previously outlined, the factors that influence exchange rates are not only those factors that reflect current conditions of demand and supply in foreign exchange markets, but also market participants' expectations about those conditions in the future. Increases (or decreases) in exchange rates, therefore, are responses to changes in both current market forces and expectations of future market conditions changes that will occur regardless of the type of exchange rate system.

\footnotetext{
TFor example: "There is broad agreement that exchange rates play an important role in the international adjustment process. . . However, in the judgment of some countries, exchange rates have deviated at times strongly in the short-and medium-term from the rates that appeared to be warranted by fundamental determinants such as price or current-account developments. In addition, it is widely felt that excessive short-and medium-term exchange rate variability has adverse consequences for domestic economic de velopments and the working of the international adjustment process," excerpted from the introduction to the Report of the Working Group on Exchange Market Intervention, established at the Versailles Summit of the Heads of State and Government (March 1983). See also Otmar Emminger, "All Nations Need An Exchange Rate Policy," New York Journal of Commerce, October 5 , 1981; Jack Kemp, "A Floating Dollar Costs Us Jobs," Washington Post, May 15, 1983; and Richard W. Rahn, "It Is Time for a New Intermational Monetary Conference," Economic Outlook, Chanber of Commerce of the United States, June 28, 1983.

${ }^{8}$ For a discussion of how official intervention may affect the exchange rate, see Dallas $S$. Batten and James E. Kamphoefner, "The Strong U.S. Dollar: A Dilemma for Foreign Monetary Authorities," this Review (August/September 1982), pp. 3-12
}

Conversely, a fixed exchange rate is one whose value is maintained by the monetary authority through variations in monetary policy. The appearance of less price uncertainty under fixed exchange rates is obtained at the cost of greater policy uncertainty. The maintenance of fixed rates implies following policies (especially monetary) that produce fixed rates. In particular, for an exchange rate to be maintained at a given level, inflation rates and real interest rates in the two coumtries cannot diverge; or, in other words, the two countries must follow monetary policies that result in such similarities. Any upward or downward pressure on the exchange rate, then, must be countered by appropriate policy changes. This uncertainty associated with potentially frequent and unpredictable policy changes in a system of fixed rates is not present in a system of floating rates. Thus, the appearance of less uncertainty with fixed exchange rates is an illusion. Consequently, the shift from a fixed to a floating exchange rate system should not have a significant negative impact on international trade.

One way of investigating whether or not floating exchange rates have had a negative impact on international trade is to examine the value of total trade (exports plus imports) as a percentage of nominal GNP over time; this is presented in chart 1 for the United States and five other major industrial countries. It is clear from this chart that since March 1973 (the date generally accepted as the beginning of the floating-rate period), there has been no decline in the ratio of trade to GNP. In fact, there is a marked increase in the trend of this ratio for some countries during the floating-rate period. ${ }^{9}$ More rigorous investigations have supported this casual analysis by failing to find any significant negative impact of floating exchange rates on international trade. 10

\footnotetext{
The trend growth rate of the ratio of trade to GNP in the floatingrate period is significantly larger in a statistical sense than that in the fixed-rate period for Germany, Japan, the United Kingdom and the United States.

${ }^{10}$ See Peter Hooper and Steven W. Kohlhagen, "The Effect of Exchange Rate Uncertainty on the Prices and Volume of International Trade," Journal of International Economics (November 1978), pp. 483-511; Bela Balassa, "Flexible Exchange Rates and International Trade," in John S. Chipman and Charles P. Kindleberger, eds., Flexible Exchange Rates and the Balance of Payments (North-Holland Publishing Co., 1980), pp. 67-80, Richard

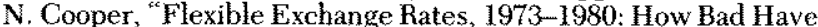
They Really Been?" in Richard Cooper, and others, eds., The Internatinal Monetary System Under Flexible Exchange Rates (Ballinger Publishing Co., 1982), pp. 3-15; and Andrew D. Crockett and Morris Goldstein, "Inflation Under Fixed and Flexible Exchange Rates," IMF Staff Papers (November 1976), pp. 509 44. For an analysis of periods other than the 1970 s see Leland $B$. Yeager, International Monetary Relations: Theory, History, and Policy, 2nd ed. (Harper and Row, 1976), pp. 252-77; and Myhrman, "Experiences of Flexible Exchange Rates in Earlier Periods."
} 
Chant 1

Total Trade as a Percentage of Nominal GNP

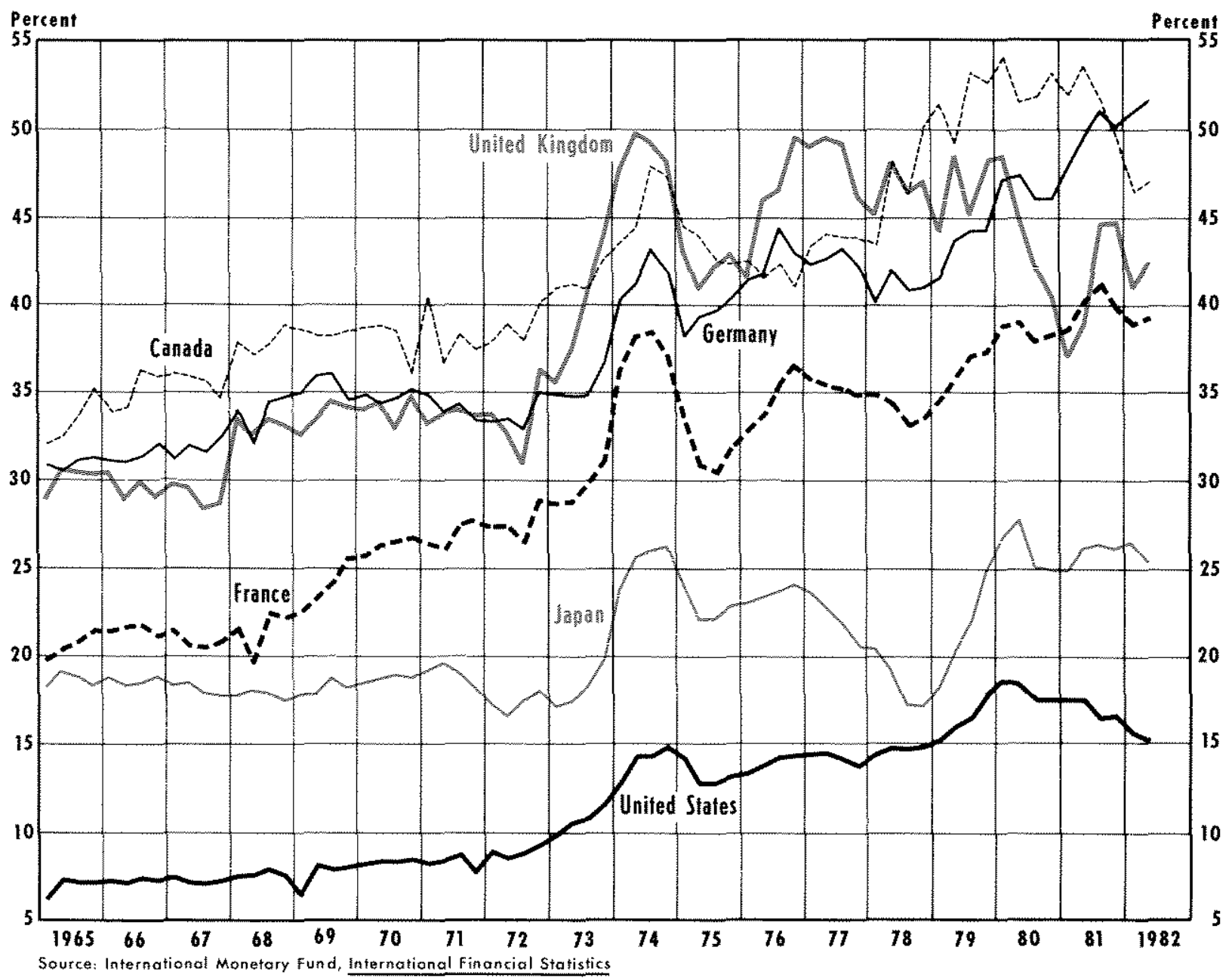

\section{MYTI 2:A DERREGITNG CUPRENGY GENERATES DOMESTIC INEIATION.}

During the period of generally floating exchange rates in the $1970 \mathrm{~s}$, most industrial countries experienced episodes of accelerating domestic inflation and exchange rate depreciation. These experiences have given rise to a school of thought that a decline in the exchange rate induces an increase in domestic inflation through an increase in the domestic-currency price of imports. But, an increase in inflation is expected to cause a further decline in the exchange rate, which causes additional inflation and so forth. "This "vicious

"See John F. O. Bilson, "The "Vicious Circle" Hypothesis," IMF Staff Papers (March 1979), pp. 1-37; Marian E. Bond, "Exchange circle" leaves little hope of ever obtaining price stability in a world of floating exchange rates.

This view confuses the relationship between exchange rates and domestic inflation in at least two ways. First, it implies that there is a causal relationship that runs from exchange rate changes to changes in the rate of domestic inflation. Second, it suggests that inflation is a cost-push phenomenon. An understanding of the relationship between money growth and

Rates, Inllation, and Vicious Circles, "IMF Staff Papers (Decem ber 1980), pp. 679-711; Crockett and Goldstein, "Inflation Under Fixed and Flexible Exchange Rates"; Panl Lewis, "France Hits Record Low; Sharper Quarrel Is Seen,"New York Times, May 28, 1983; Robert D. Hormats, "Currency-Rate Lessons," New York

Times, March 27, 1983; and Robert Solomon, The International Monetary System, 1945-1981 (Harper and Row, 1982), pp. 298 315. 
inflation, however, should dispel each of these conceptual errors.

\section{Whaton a Monetary Phenomenon}

A country's money supply essentially is determined by its monetary authority; the demand for money (i.e., an individual's desire to hold a portion of his wealth in the form of money) is determined primarily by income, real interest rates, prices and price expectations in that country. The equilibrium rate of inflation is the one at which the growth rate of the money supply equals the growth rate of individuals' desired money holdings. Any other inflation rate motivates individuals to alter their spending rate in an attempt to change their money holdings at a rate different from the rate at which the money supply is growing.

A monetary disequilibrium, through its impact on the rate of aggregate spending, simultaneously induces changes in the rate of domestic inflation and the foreign exchange rate. That is, changes in the rate of consumer spending affect not only domestically produced goods and services but also those produced abroad. Altered demands for foreign goods and services, in turn, produce changes in U.S. demand for foreign currencies and as a consequence, changes in the foreign exchange value of the dollar, all other things equal. Thus, the rate of domestic inflation and changes in the exchange rate are determined jointly by the rate of domestic money growth relative to the growth of the amount that individuals, domestic and foreign, desire to hold.

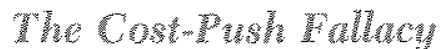

The cost-push explanation of inflation is supported neither by economic theory nor empirical evidence. ${ }^{12}$ This non-monetary explanation of inflation suggests that an exchange rate depreciation raises the domestic currency prices of imported goods and services and, consequently, the cost of living. Wage demands, and subsequently, wages, are presumed to rise to compensate for the increased cost of living. Higher wages would mean higher production costs and, as a result, producers would raise the prices of their commodities. The cost of living would rise, once again initiating a "wage-price spiral" and the vicious circle. This spiralling of wages and prices would be exacerbated within an international framework as the exchange rate would continue to depreciate with rising domestic prices, generating even more inflationary pressure.

\footnotetext{
"Lee Dallas S. Batten, "Inflation - The Cost-Push Myth," this Review (June/July 1981), pp. 20-26.
}

This argument confuses a change in relative prices with inflation. A depreciation of the foreign exchange value of a currency does raise the domestic currency prices of imported goods relative to the prices of those produced domestically. Other things equal, the higher prices of imports would cause the overall price level to rise. The rise in import prices, however, sets in motion both an adjustment in the public's money holdings and in its demand for non-traded goods - that is, domestically produced goods that are not internationally traded.

First, the relative increase in the price of imported goods temporarily causes a rise in the rate of inflation; in response, the public increases the rate of growth of its desired money balances. If the rate of growth of the money supply remains constant, there will not be enough additional money available for a new monetary equilibrium to be reached, given this higher rate of inflation. Consequently, in order to increase the rate of growth of their money balances to the desired rate (that is, the equilibrium rate after the exchange rate depreciation), individuals must decrease their spending rate on goods and services, both traded and non-traded.

Second, a decreased growth rate of aggregate spending brought about by the attempt to increase money balances causes a decline in the rate of price growth in those sectors of the economy that produce non-traded goods until the overall rate of inflation is the same as it was before the depreciation. The rate of inflation must decline to its original value - that which equates the growth rate of the money supply to that of money demand; it is, after all, the only rate of inflation that can be sustained without a change in the rate of money growth.

Of course, this adjustment in the rate of price growth in the non-traded goods sector does not occur immediately. During the adjustment period, the cost of adjusting is reflected by a decline in the growth of real output (and by a corresponding decline in employment). If the monetary authority confuses this with a permanent decline in the rate of aggregate demand, it may increase the rate of growth of the money supply. This action would accommodate the impact of the currency depreciation and allow the inflation to persist. That is, the cause of the vicious circle has been neither the depreciating currency nor the regime of floating exchange rates that allows such adjustments, but rather the accommodation by the monetary authority. ${ }^{13}$ Such a policy response to changes in the

\footnotetext{
${ }^{1.3}$ For additional support, see Bilson, "The "Vicious Circle' Hypothesis"; and Bond, "Exchange Rates, Intlation, and Vicious Circles."
} 
Chort 2

\section{The Inflation Differential and the Exchange Rate}

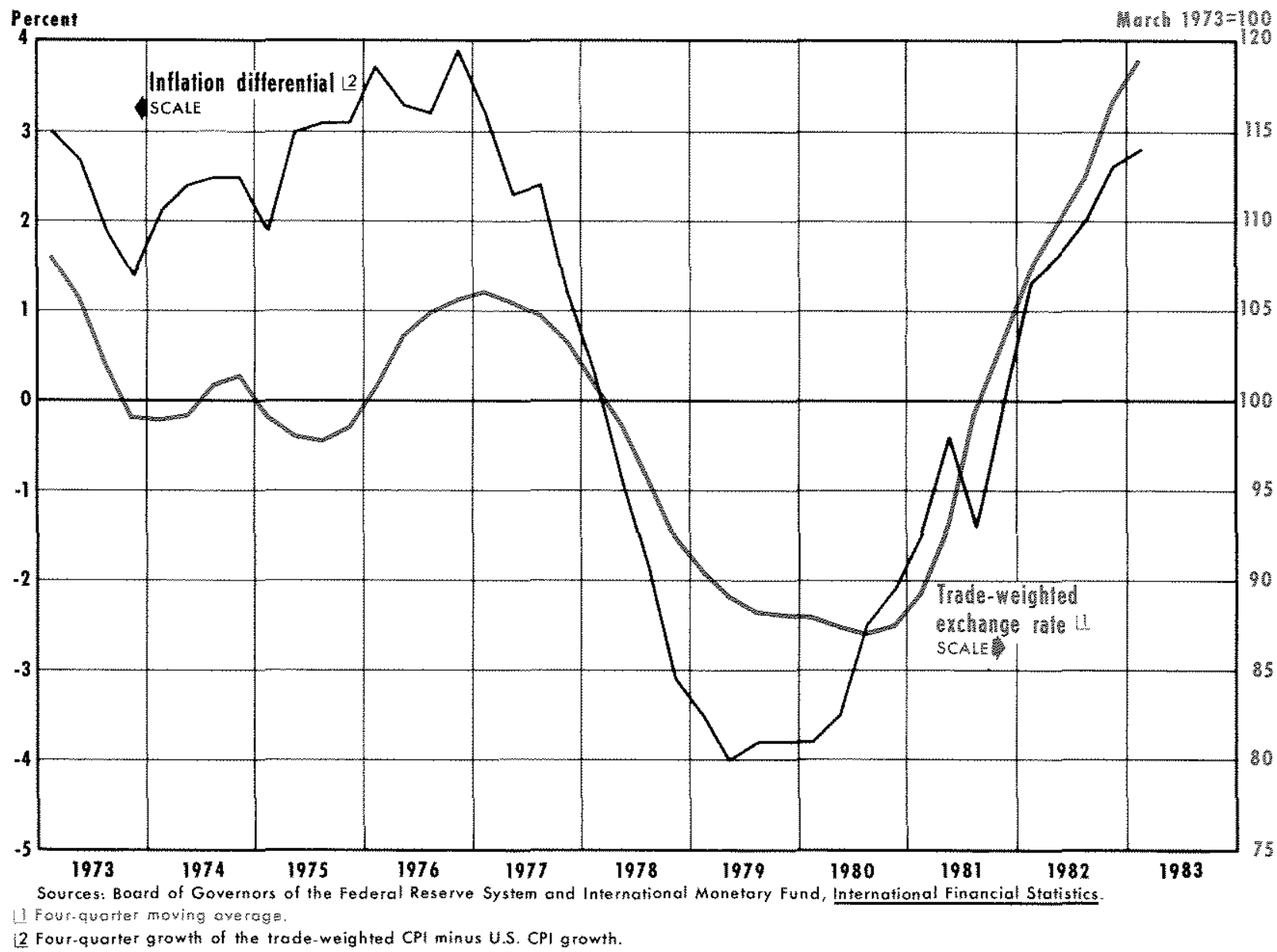

relative prices of traded and non-traded goods creates the illusion of cost-push inflation, when in fact, the increased rate of inflation is generated by the increased rate of money growth.

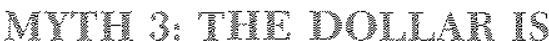 OVITVAULD.}

A variety of pundits have claimed that the dollar is overvalued. ${ }^{4}$ The natural question this suggests is:

\footnotetext{
${ }^{14}$ For examples, consider: "Most of this country's current tade troubles - the falling exports, the disputes over other countries" trading tactics, the alleged decline of American industrial competitiveness - are the result of an overpriced dollar, lifted by high interest rates." "Mr. Regan's Embarrassing Dollar," Washington Post, May 4, 1983; "Peter G. Peterson, Chairman of Lehman Brothers Kuhn Loeb, agreed on the question of budget deficits and argued that the dollar is 20 to 25 percent overvalued on a trade-weighted basis. In a year it will be more than that." Ripley
}

"With respect to what is the dollar overvalued?" In the main, individuals who claim that the dollar is overvalued are arguing that purchasing power parity currently does not hold.

As noted in our earlier discussion, short-run departures from PPP are common and, hence, tell us little about the over- or undervaluation of the dollar. Consequently, RPPP is a better indicator of the dollar's value in the short run. According to RPPP criterion, the exchange rate should change roughly in accordance with changes in inflation rate differentials. ${ }^{15}$ To illustrate this relationship, the trade-weighted dollar ex-

Watson, Jr., "Two Obstacles to Economic Growth Cited," New York Journal of Commerce, May 3, 1983.

${ }^{15}$ Even here however, short-run departures will be common. See Frenkel, "Flexible Exchange Rates, Prices, and the Role of 'News'," pp. 693-99 
change rate and the trade-weighted inflation rate differential are graphed in chart $2 .{ }^{16}$ There is a clear correspondence between the two series; as implied by RPPP, changes in the trade-weighted exchange rate have reflected changes in the tradew weighted inflation rate differential. ${ }^{17}$

\section{Monetary Growsh and he Speed of Exchange Rate Adhatment}

Given the corrective forces brought to bear through floating exchange rates, it is puzzling that any currency could be over- or undervalued persistently. Yet, in the short-run adjustment to a monetary disequilibrium, producers probably cannot discern immediately whether the resulting change in aggregate demand (spending) is permanent or merely temporary. Thus, they respond initially by changing their rate of production. That is, the change in money growth results in a deviation of real economic activity from its "normal" rate. Only when this change in spending is recognized as permanent will producers change their prices and attempt to return their production to its normal rate. Hence, the impact of the monetary disequilibrium on output eventually vanishes, leaving only the rate of inflation permanently affected. These long-run adjustments, however, are not realized immediately,

On the other hand, the exchange rate responds to a monetary disequilibrium more rapidly than do the prices of domestic commodities. ${ }^{1 S}$ This more rapid adjustment occurs because the exchange rate is the relative price of two assets and, unlike commodity

\footnotetext{
${ }^{16}$ The trade-weighted exchange rate is an average of the value of the U.S. dollar against 10 other currencies, weighted by each courttry's trade share, relative to a base value of 100 in March 1973. The countries included are Belgium, Canada France, Germany, ItaIy, Japan, the Netherlands, Sweden, Switzerland and the United Kingdom. For a more detailed explanation see "Index of the Weighted-Average Exchange Value of the U.S. Dollar: Revision," Federal Reserve Bulletin (Algust 1978), p. 700. The tradeweighted inflation differential, as usually expressed, is the difference between the rate of growth of the U.S. CPI and the rate of growth of the trade-weighted foreign CPI for the same countries asing the same weights as above. The trade-weighted nominal interest rate differential which is used below is the difference between the U.S. 3-month commercial paper rate and a weighted average of comparable foreign interest rates for the same countries using the same weights as above. The trade-weighted real interest rate differential is an ex post neasure calculated as the difference between the trade-weighted nominal interest rate differential and the same period's trade-weighted inflation rate differential

${ }^{17}$ The correlation coefficient between the trade-weighted exchanget rate and the trade weighted inflation differential over the 1973-83 period was 0.780 ; the correlation coefficient between changes in the two series was 0.533 .

${ }^{8}$ See Mussa, "Empirical Regularities," pp. 22-24.
}

prices, is determined in highly organized, internationally integrated markets that quickly and efficiently assimilate new information. Consequently, the exchange rate will change before commodity prices change sufficiently to regain a domestic monetary equilibrium.

During this adjustment period then, a currency will be over- or undervalued in the sense that the PPP condition will be violated. In the long run, however, the rate of domestic inflation generally will change sufficiently to offset deviations from PPP that may have existed in the short run. ${ }^{19}$

These deviations of exchange rates from PPP have engendered support for increased official intervention in foreign exchange markets. ${ }^{20}$ Since these deviations may either be random fluctuations or represent short-run disequilibria, there is no reliable method of discerning the cause of short-run exchange rate movements. ${ }^{21}$ Consequently, policy actions are inappropriate and actually may exacerbate the equilibrating process, thereby lengthening the period of adjustment. ${ }^{22}$

Finally, the overvalued dollar myth can also be interpreted as a complaint about domestic capital market conditions that cause the dollar's value to rise above what it otherwise would be. That is, the federal budget deficit may cause domestic interest rates to rise inviting a flow of capital to dollar-denominated assets,

\footnotetext{
192ven though the PPe condition has been violated frequently in the short run during the $1970 \mathrm{~s}$, there is no evidence that its usefulness as a condition of long-run equilibriam has been mitigated. See Jacob A. Frenkel, "The Collapse of Purchasing Power Parities During the 1970s," European Economic Revieu (May 1981), pp. 145-65.

${ }^{20}$ See, for example, Valery Giscard d'Estaing, "A Communique for Williamsburg," The Economist (May 21, 1983), pp. 15w18; Hel. mut Schmidt, "The World Economy at Stake," The Economist (February 26, 1983), pp. 19-30; Hobart Rowen, "Fed Chief Asks Action on Dollar," Washington Post, April 19, 1983; Paul Lewis, "U.S. Assailed in France Over Strength of Dollar," New York Times, April 21, 1983; and "Exchange Rate Woes Must Be Addressed,"Washingon Post, April 17, 1983.

${ }^{21}$ Martin Feldstein, chairman of the President's Council of Economic Advisers, recently wrote: "[T] distinguish an exchange-rate movement that is merely a random fuctuation from one that is part of a fundamental shift in the equilibrium exchange tate. Exchange-market intervention aimed at smoothing a transitory disturbance may in fact be a counterpro. ductive or fatile attempt to prevent a basic shift in the equilibrium exchange rate." Martin Feldstein. "The World Economy Today," The Economist (June 11, 1983), p. 48. See also Mussa, "Empirical Regularities."

${ }^{22}$ See Frenkel, "Flexible Exchange Rates, Prices, and the Role of "News" "; and Dean Taylor, "Official Intervention in the Foreign Exchange Market, or, Bet Against the Central Bank," Journal of Political Economy (April 1982), pp. 356-68.
} 
thereby boosting the dollar's exchange rate. ${ }^{23}$ of course, this does not result in an "overvalued" dollar. Rather, it explains why its value is "high"; demand for a currency may violate PPP for a sustained period if an economy's asset yields in real terms are different than those of its trading partners. As such, complaints about an overvalued dollar are really complaints about policies causing a "high" exchange rate and should not be considered as criticisms of the floating exchange rate system.

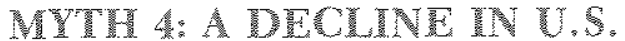 INTRREST PATIS WULI CAUSE THE FXCHANGE RATE TO FALL}

It is widely alleged that changes in U.S. market interest rates relative to those in the rest of the world are the major determinants of short-run movements in the foreign exchange value of the dollar. ${ }^{24}$ Yet, it is changes in real, not nominal, interest rate differentials that actually motivate the international movement of financial capital and, therefore, induce changes in exchange rates.

The interest rates quoted in financial markets are nominal interest rates. Each nominal interest rate can be divided into two components: the real interest rate (or real yield) and a premium for expected inflation. The real interest rate represents the payment to the lender (in terms of the ability to consume more real goods and services later) necessary to induce him to forego some of his current consumption. The inflation premium is the compensation for the erosion of purchasing power expected to occur during the life of the loan. The nominal interest rate is approximately the sum of these two components.

The key to understanding the short-run impact of relative changes in nominal interest rates on the foreign exchange value of the dollar, then, is to recall the implications of the fourth and fifth elements of exchange rate determination - namely, relative purchasing power parity and interest rate parity. RPPP

\footnotetext{
29) Feldstein holds such a view:

"According to his analysis, the current high exchange rate of the dollar is produced by the anticipation of huge federal budget deficits, which in turn cause real interest rates to go up. The real interest rate increases boost the value of the dollar, and thus cause the larger trade deficit (as U.S. goods are marked up).

'In short, budget deficits beget trade deficits, and this requires a high exchange value of the dollar, "Feldstein said." Hobart Rowen, "Feldstein Says U.S. Should Not Weaken Dollar," Washington Post, April 8, 1983. See also, "Dollar and Deficit, Both Too Strong," New York Times, June 3, 1983.

${ }^{24}$ See, for example, John M. Leger, "Dollar's Strength Stuns Many Traders; More Gains by U.S., U.K. Units Predicted," The Wall
}

implies that exchange rates will move to offset changes in inflation rate differentials. Thus, as we saw in chart 2 , a rise in the U.S. inflation rate relative to those of other countries will be associated with a fall in the exchange value of the dollar. Conversely, IRP implies that a rise in the real interest rate in the United States relative to that of other countries will cause the exchange value of the dollar to rise. Changes in the nominal interest rate differential, however, can be due either to changes in the relative inflation outlook or in the relative real yields between the United States and its trading partners. Since the two components of the nominal interest differential have opposite effects on the exchange rate, it is not clear, a priori, whether a change in the nominal interest rate differential will raise or lower the exchange rate.

As shown in chart 3 , there is a rough correspondence between the trade-weighted real interest rate differential and the trade-weighted exchange rate for the United States since 1976. Periods when the exchange rate was declining also tended to be periods when the real interest rate differential was declining and vice versa. Conversely, as the chart reveals, there have been periods when the exchange value of the dollar and the nominal interest rate differential have moved in the same direction, but there also have been many periods when they have moved in opposite directions. That is, changes in the nominal interest rate differential, at times, have been dominated by changes in the real interest rate differential but, at other times, have been dominated by relative changes in inflationary expectations. ${ }^{25}$ Consequently, there is no stable, predictable relationship between nominal interest rate differentials and the exchange rate.

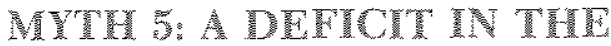 INT TWADE ACOOUNT WIIL CAUSE A

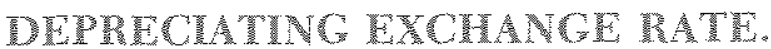

This myth alleges that the relative value of a country's currency is determined primarily by the differ-

\footnotetext{
Street Journal, June 8, 1983; "The Dollar's Surprising Strength," International Finance, Chase Manhattan Bank, September 13 , 1982; "What Keeps the Dollar Mighty," Business Week (September 6, 1982), p. 73; and "Mr. Regan's Embarrassing Dollar," Washington Post, May 4, 1983.

${ }^{25}$ Indeed, for this eight-year period, the correlation coefficient between the trade-weighted exchange rate and the nominal interest rate differential was -0.331 indicating that relative inflation expectations outweighed real yield differentials. The correlation between the exchange rate and the real yield differential was, as theory predicts and chart 2 shows, positive $(0.661)$.
} 
Chat 3

\section{Interest Rate Differentials and the Exchange Rate}

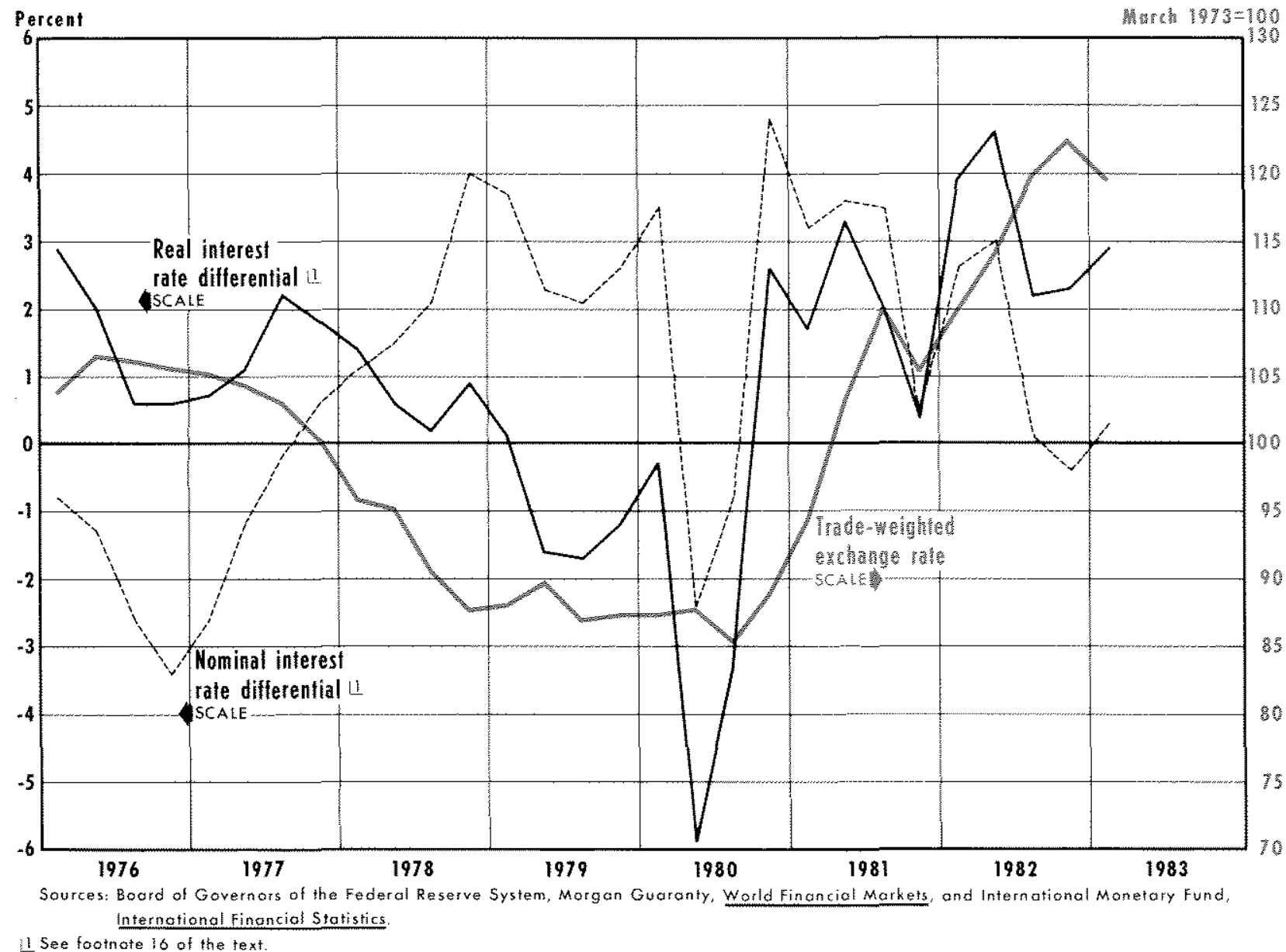

ence between its exports and imports of merchandise. ${ }^{26}$ Yet, currencies flow between countries not only to finance merchandise trade, but also to finance investment (capital flows) and to pay for services. Hence,

\footnotetext{
20 Three examples of this are: "Most economists, however, believe that the follar is due for a fall this vear (to help correct the huge U.S. trade deficit), whatever happens to the EMS." Gary Yerkey, "On thth Anniversary, Europe's Money System Rejigs," Christian Science Monitor, March 22, 1983.
}

"TThe impact of an expected weakening in the dollar later this vear [is] in response to allarge and growing U.S. trade deficit." Lawrence Chimerine, Executive Summary U.S. Macro, Chase Econometrics, July 27, 1983, p. 2.

"Trade deficits cannot continue at current levels. We have to sell as well as buy abroad. Export earnings must come nuch closer to paying our import bills." Richard D. Lamm, "The Seven Deadly Economic Sins," Christian Science Monitor, August 3, 1983. exchange rates reflect all of these flows as well as expectations concerning future changes in them.

The importance of capital inflows was discussed earlier. The role of income from capital services due to previous investments, however, almost always is overlooked in media discussions of exchange rates. ${ }^{27}$ That is, American investors (individual and corporate) re-

\footnotetext{
${ }^{27}$ Two exceptions to this neglect are Alfred I. Malabre, Ir. "Service Transactions Keep Balance of Trade In Surplus Despite the Large Deficit on Goods," The Wall Street Journal, February 10, 1982 ; and Robert A. Feldman and Allen ]. Proctor, "U.S. International Trade in Services," Federal heserve Bank of New York Quaterly Review (Spring 1983), pp. 30-36. Moreover, the currently strong dollar may increase U.S. foreign investment that will, in turn, contribute to further rises in future investment income. Soe, for example, "Dollar Fever Infects the World," Business Week (June 27, 1983), pp. 90-100
} 
Chant 4

\section{The Balance of Payments and the Exchange Rate}

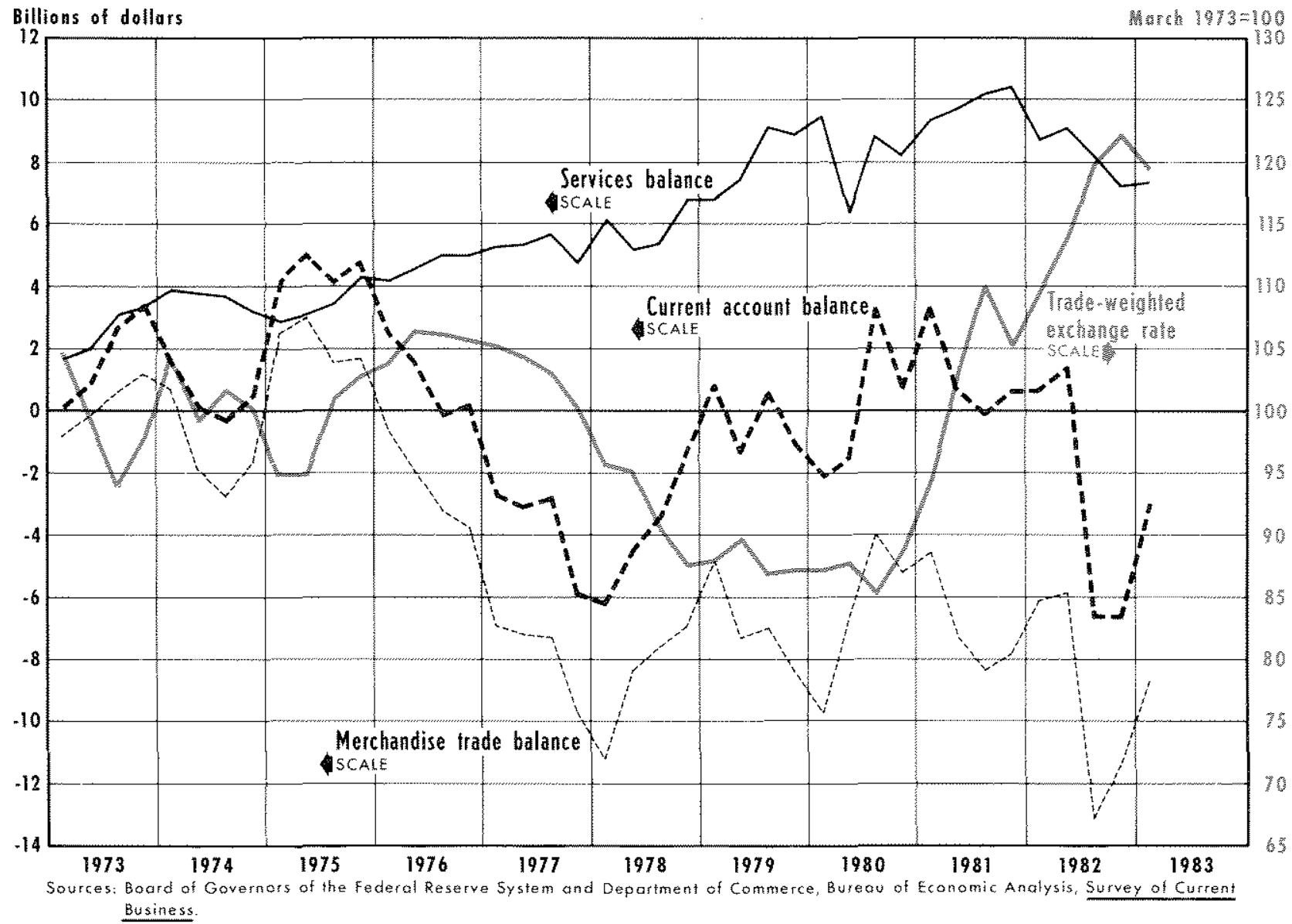

ceive income from assets held in foreign economies; these service exports - particularly the services of the American-owned capital in foreign countries - offset merchandise imports and allow the United States to run a persistent merchandise deficit without necessarily inducing a decline in the exchange rate. Thus, the balance of trade that is relevant for anticipated exchange rate movements is not the merchandise trade balance alone, but rather the more inclusive current account balance, which includes services and government transfers as well.

As shown in chart 4 , the current account has exhibited no apparent trend, but rather has fluctuated around zero during the floating rate era, 1973-83. While the merchandise trade balance has been consistently in deficit since 1976 , the services balance (which is primarily investment income) generally has offset it. There is no apparent explanation in chart 4 for the significant rise in the trade-weighted exchange rate since mid-1980. Consequently, a continuation of deficits in U.S. merchandise trade need not cause a depreciation of the U.S. exchange rate.

\section{CONCUSOR}

Exchange rates are determined by the actions of participants in active, internationally integrated currency markets. These markets reflect the information - the economic conditions, plans and expectations assimilated by a diverse set of participants. Exchange rates adjust quite rapidly to incorporate any new information provided to these markets but, perversely, some of the economic processes that the information describes may be protracted. For example, internationally traded goods' prices adjust almost contemporaneously with changes in exchange rates, but 
non-traded goods' prices adjust more slowly. Consequently, full adjustment to purchasing power parity takes place with a lag. Indeed, this adjustment can be counterposed by movements of real interest rates, which could cause exchange rate movements to be quite volatile during the progression to a long-run equilibrium.

While at any time there exists an exchange rate that incorporates all of this information, the conflicting influences emanating from different forces - for example purchasing power parity versus interest rate parity - may mislead individuals whose focus is on a single determinant of exchange rates. Furthermore, either misapprehension of the actual forces - say, nominal as opposed to real interest rate differentials - or an incomplete specification of the determination of exchange rates - a trade flow approach as opposed to an asset market approach - will produce a faulty under- standing of why exchange rates move and how these movements affect the domestic economy.

In this article we have examined five common myths concerning floating exchange rates that arise from such incomplete understanding. Perhaps, by clarifying the mechanism of exchange rate determination, the temptation to blame floating exchange rates for international and domestic crises can be counteracted. ${ }^{28}$ It should be clear that floating exchange rates reflect international economic conditions in a somewhat predictable way; they do not create them.

${ }^{20}$ See, for example, Kemp, "A Floating Dollar Costs Us Jobs"; d'Estaing, "A Communique for Williamsburg"; Jacques R. Artus,

"Toward a More Orderly Exchange Rate System," Finance and Development (March 1983), pp. 10-13; Leonard Silk, "Fixed Rates May Be Better," New York Times, March 23, 1983; Helen Ericson, "New Monetary Alternatives Urged," New York Journal of Commerce, May 25, 1983; and "A Call To Sink Floating Ex" change Rates,"Business Week (May 16, 1983), p. 147. 